Ranko Grujić ${ }^{*}$, Miladin Gligorić ${ }^{2}$, Božo Dalmacija ${ }^{3}$, Vaso Novaković ${ }^{1}$, Srđan Rončević ${ }^{3}$, Časlav Lačnjevac ${ }^{4}$

1"IPIN" Ltd., Bijeljina, Institute for applied geology and hydroengineering, $R S, B i H,{ }^{2}$ University of East Sarajevo, Faculty of Technology Zvornik, RS, BiH, ${ }^{3}$ University of Novi Sad, Faculty of Sciences Novi Sad, Serbia, ${ }^{4}$ University of Belgrade, Faculty of Agriculture, Belgrade,Serbia

\section{Scientific paper}

ISSN 0351-9465, E-ISSN 2466-2585

UDC:628.193:551.435.17(282.243.7)

doi:10.5937/ZasMat1603460G

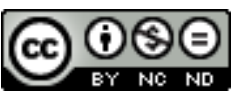

Zastita Materijala 57 (3) 460 - 472 (2016)

\title{
Modelling transport polluting substances into alluvial sediments of the Danube River near Novi Sad
}

\begin{abstract}
The paper analyzes the behavior and interaction of water and the environment in different conditions of groundwater regime. Based on the quality of groundwater i.e. physical-chemical and microbiological characteristics of water from source in the alluvions of the Danube and water quality of the Danube River, we can assume the possible impact on the quality of the river water source in Novi Sad.

Good knowledge of the sources and quantities of accumulated pollutions in the sediments and hydrogeological conditions in aquifers in a particular period are crucial for proper placement of the conceptual model of the aquifer. Properly set conceptual model has a crucial role for good mathematical model of pollution transport in aquifer. Water source Strand near Novi Sad has been selected for the modeling because the data on the water quality of this water source and characteristics of alluvial sediments are very well researched.
\end{abstract}

Key words: groundwater, alluvium, sediment, transport, pollution, mathematical model.

\section{INTRODUCTION}

To date acquired knowledge of the alluvial sediments of the Danube and natural characteristics in the alluvial belt to which the ground waters have accumulated are available to us on the basis of previous geological and hydrogeological studies. The Danube alluvial belt geomorphologically represents alluvial terrace formed on both sides of the River Danube. Groundwaters in the Danube alluvial zone are located in the aquifers of sand-gravel alluvial sediments of Quaternary age at a depth of $20-30 \mathrm{~m}$ and they have a good contact with the Danube, which enables very good recharge from the direction of the river. Characteristic of this belt is that it extends all the way from Budapest till the end of the Pannonian Plain. The roof aquifers consist of less permeable layers of clay and sandy clay, whose thickness is variable, and in the area Novi Sad they amount to an average of about $4 \mathrm{~m}$. Shelf consists of Pliocene sediment which continuously spreads to a wider area [1-5]. Due to the

\footnotetext{
${ }^{*}$ Corresponding author: Ranko Grujić

E-mail: rankogrujic74@gmail.com

Paper received: 20. 04. 2016.

Paper accepted: 22. 05. 2016.

Paper is available on the website: www.idk.org.rs/journal
}

increasing needs for drinking water of the population and economy of the wider area of Novi Sad, it was necessary to do a large amount of research, elaborates, projects and studies on the basis of which the potential water source has been determined. Recharge of aquifers is done through the infiltration of waters of the Danube - which is directly linked on the degree stuffy bottom of the river, the water level in the river and local geological conditions within the aquifer protection and another way infiltration of water from the hinterland catchment areas water sources. The water from the alluvial sediments for water supply of Novi Sad is used into three water sources: Strand, Petrovaradinska ada and Ratno ostrvo (War Island).

The necessary protection of water sources is hampered because the same are located in populated areas of the city or near the industries. Monitoring of groundwater behind the water souce made it possible to get information on the movement of pollution in the direction of the wells in the zone of water source. The use of monitoring data helped us to the analyses of pollution transport and based on the locations of the occurrence of pollutants, the time of arrival of the front of pollution to water intake facilities was determined. In this way it is possible to give a rating of the vulnerability of certain reny wells in water sources, as well as sources of vulnerability of 
the wider area. Also, based on the obtained data give the proposal the necessary measures to prevent pollution of water sources and the space behind the water sources. The information obtained from monitoring was used for defining the preventive and corrective measures for the protection of water sources.

The quality of groundwater is specific for individual aquifers, whixh is expressed through the physical-chemicals characteristics with special reference to the content of pollution [6].

The goal of mathematical modeling of groundwater is to solve complex problems which occur during the study of the movement of groundwater, to predict the possible directions of pollution transport and broadly speaking, to find about the physical-chemical processes which occur in ground waters and the environment through which it passes through. All this can be achieved by using a model. The models are the basis for the presentation of the actual situation on the ground. These are the tools that help us in understanding the interaction between the movement of groundwater and the environment through which it passes. Models of pollution transport explain the procedures behavior of certain parameters of the hydrogeological environment and parameters of water quality and their interactions in time [7-9]. Mathematical models today are common practice in the world and they use a variety of computer tools for research of environmental influences on the quality of groundwater.

Testing of groundwater is mainly done from the upper aquifer to a depth to $30 \mathrm{~m}$. Water quality is monitored for Reny wells, shallow and deep piezometers near the wells, in the wider area of water sources and near the sources of pollution, i.e. to the directions of possible penetration of pollution. Analyses were performed according to standard methods for determining the hygienic safety of water for drinking. Analises have shown a high degree of contamination of water sources in Novi Sad.

The process of modeling pollution transport used the following methods: modeling method using analytical elements with the use of the program Aquifer Win 32 and modeling using the 3D mathematical model using one of the most sophisticated commercial software for the simulation of groundwater flow Groundwater Vistas version 6 with the use of all related add-ons that serve as movers of simulation model for a certain period of time.

In modeling of underground flow mathematical model is presented with partial differential equations [10]. The basic equation of the mathematical model is represented by the following differential equation (1), which shows the process of threedimensional movement of groundwater constant density trough the alluvial sediments.

$\frac{\partial}{\partial x}\left(K x \frac{\partial \boldsymbol{h}}{\partial x}\right)+\frac{\partial}{\partial y}\left(K y \frac{\partial \boldsymbol{h}}{\partial y}\right)+\frac{\partial}{\partial z}\left(K z \frac{\partial \boldsymbol{h}}{\partial z}\right) \pm W=S s \frac{\partial \boldsymbol{h}}{\partial t}$

where:

$x, y, z$ - axis of the right-angled coordinate system $(\mathrm{m})$;

$K x, K y, K z$ - component of filtration coefficient $(\mathrm{m} / \mathrm{s})$;

$H$ - piezometrical level $(\mathrm{m})$;

$W$ - volume flux (flow) per unit volume $\left(\mathrm{S}^{-1}\right)$;

$S s$ - coefficient of specific yield a porous medium $\left(\mathrm{L}^{-1}\right)$;

$t$ - time (s).

The solution of the equation is obtained when the algebraic expression for $h(x, y, z, t)$, which is an excerpt from $h$ in space and time, satisfies the equation (1), for given initial and boundary conditions. In fact, the solution for this equation is only possible for very simply flow conditions of underground water. Since the conditions are generally more complex, the solution was prepared using different numerical methods in the course of mathematical modeling for obtaining approximate solutions [11].

Transport of pollutants in alluvial sediments depends on the hydrogeological characteristics and water quality parameters and their interactions in time. Some basic aspects of the interaction of pollutants and environments are: advection, hydrodynamic dispersion, adsorption, biodegradation and others. [12-14].

Especially increased pollution of aquifers has been registered at the water source Štrand. Quality of groundwater at the source Strand was monitored with more parameters, where, apart from the basic water quality parameters, the following are included: total oils and fats, mineral oil, BTEX, VOC, $\mathrm{PAH}$, vinyl chloride, sodium and microbiological quality of water. This water source has not been used since 2010, when it was shut down. Due to the exclusion of water sources from the use, was made model transport of pollution for water source Štrand.

Pollution transport is modeled with two parameters of vinyl chloride as a typical representative of the pollution from industry and sodium, which is a representative form of anthropogenic pollution generated in households [15].

Vinyl chloride can originate from anthropogenic and natural sources. When it comes to anthropogenic sources of vinyl chloride, we must point out the industrial production of PVC and the usage 
of degreasers in industry. Besides the industry, possible anthropogenic sources of vinyl chloride are accidents that occur in transport of vinyl chloride, as well as the creation of vinyl chloride during the processes of dechlorination of PCE, TCE and DCA. Potential natural sources of vinyl chloride are the following: fires, volcanic activities, chemical processes in geological formations, photo-chemical processes and biological processes, which, in this case, are not a source of vinyl chloride [16].
Based on the analysis of the groundwater source Štrand during 2009-2010 and prior to disconnection of the water source, extremely high concentrations of vinyl chloride (over $600 \mathrm{mg} / \mathrm{l}$, MDK = $0.5 \mathrm{mg} / \mathrm{I}$ ) and sodium (above $250 \mathrm{mg} / \mathrm{I}$, natural background for sodium is $20 \mathrm{mg} / \mathrm{I}$ ) have been found. Elevated levels of pollution of vinyl chloride and sodium at the water source Štrand are shown in Figure 1.

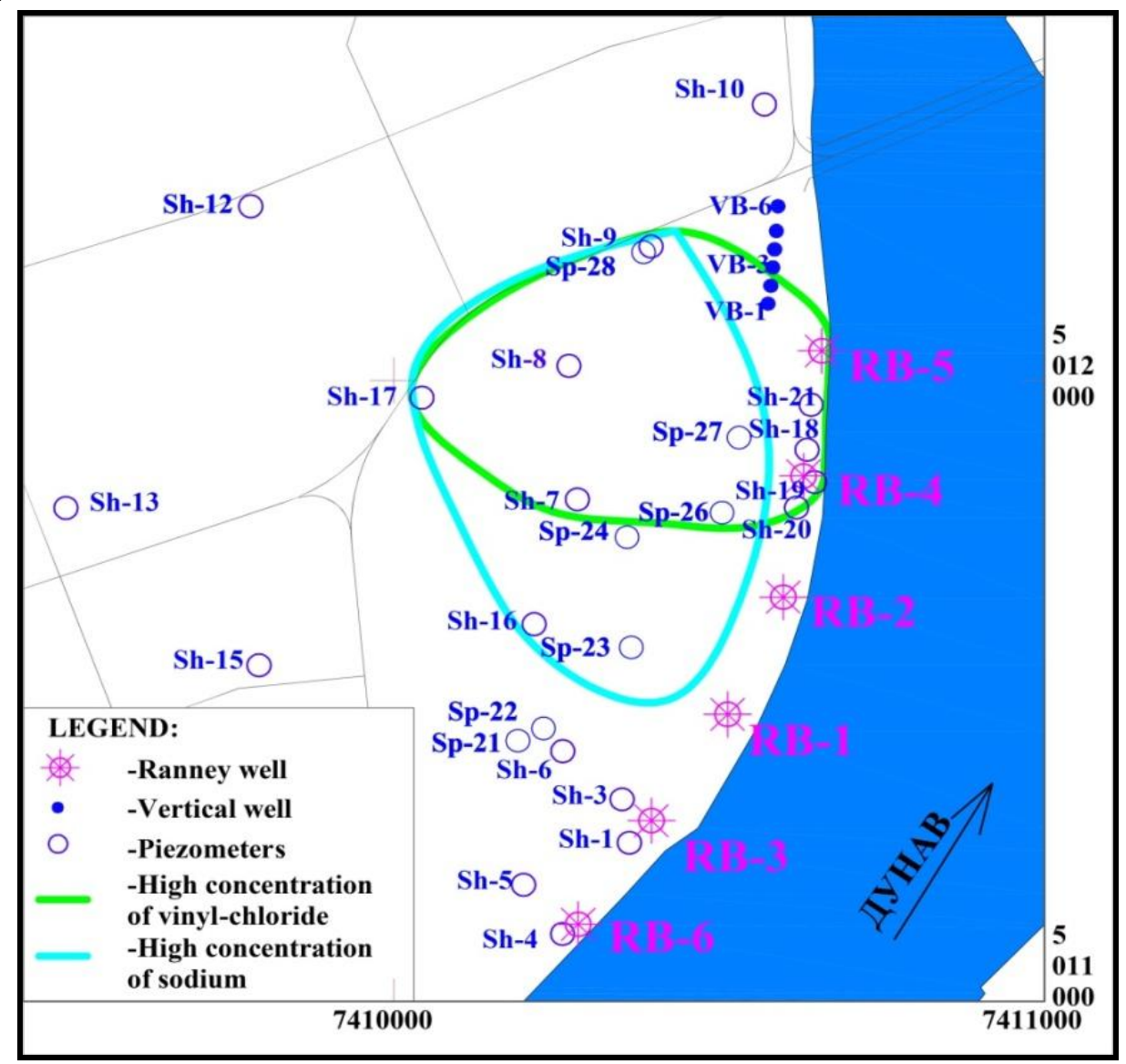

Figure 1 - The concentrations of vinyl chloride and sodium on the water source Strand

\section{THE EXPERIMENTAL PART}

The mathematical modeling of transport of pollution in the water source Štrand has been done through three phases:

- the first phase is mathematical modeling with the method of analytical elements,

- the second phase is making the numerical model, and

- the third phase is making the model of transport of pollution.

The part of the area of water source, where flow processes of groundwater happen, include the model of water source Štrand. All water intake objects of water source Štrand are located in this area.
Conceptual 3D model with the layout layers in the water source Štrand (4 layers) is presented in figure 2 .

The calculation of average values of overlying layer and bottom layer as required by the software package Aquifer Win 32 were made for the modeling method of analytical elements.

During the making of numerical model in the process of modeling, actual lithological composition was used, and it was shown by the geological and hydrogeological cross sections in the water source Strand with absolute elevations of height of distribution of the layers. 


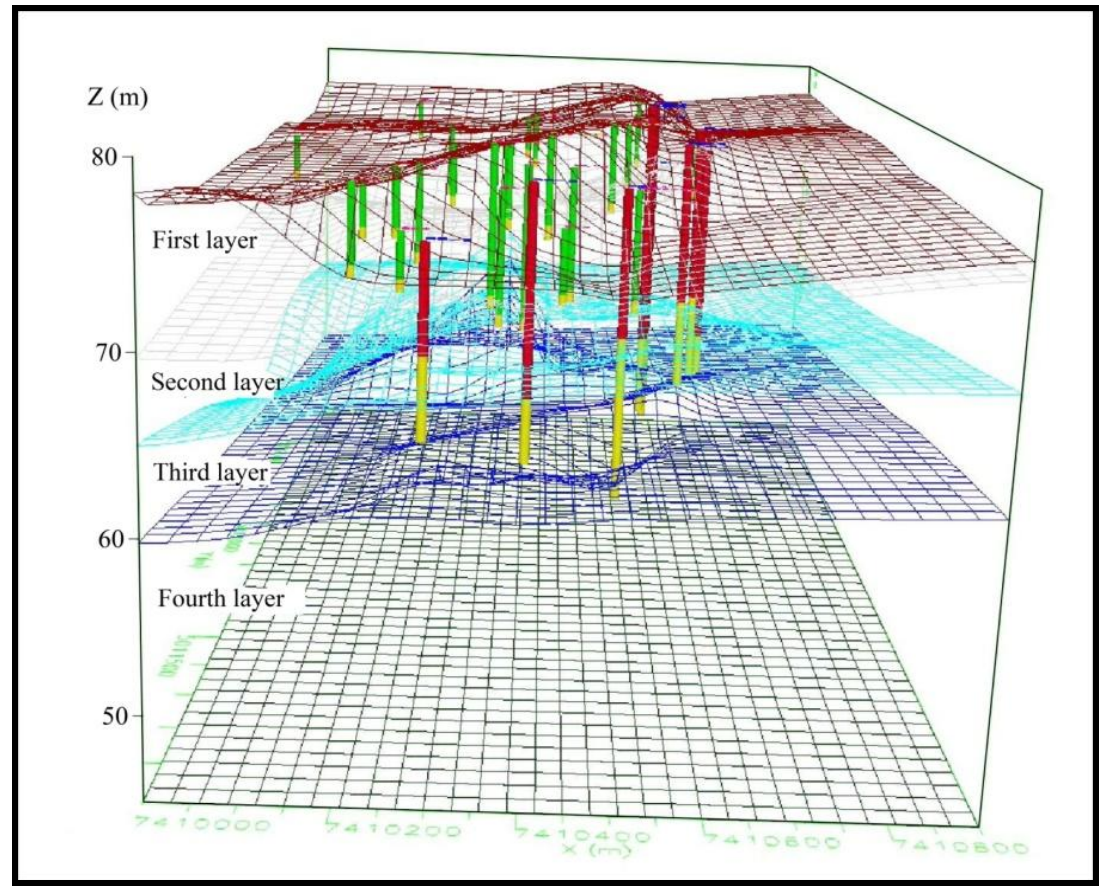

Figure 2 - Conceptual 3D model with the layout layers in the water source Štrand

The process of transport of pollution in the water of alluvial sediments is characterized by physical, chemical and biochemical interactions between the liquid phase (groundwater) and solid phase (hydrogeological environment) during the passage of the pollution through the aquifer.

\subsection{Mathematical modeling with the method of analytical elements}

Program Aquifer Win 32 version 4 was used as the first step in the mathemathical modeling. This program allows the simulation of the movement of groundwater with the method of analytical elements in the 2D horizontal plane. Although the method is limited to stationary flow, it allows fast and efficient analysis of a hydrogeological system. This is particularly important in the early stage of research when we do not have sufficient data. Even in the initial stages of considering the problems it was clear that it is not possible to simulate a complete distribution of alluvial sediments (when the borders model identical with the physical limits), the model will have "artificial" hydraulic boundary conditions. The aim of making this analytical model is the precise determination of the western boundary conditions for the numerical model.

The use and application of analytic elements significantly are different from the application of conventional numerical methods. The solution obtained by this method is not sensitive to the exchange of model, which can be from a few tens of meters to tens of kilometers.

The possibility of simulation only of the stationary conditions of movement of groundwater is the most limit of method of analytical elements.
The area of the analytical model is $14 \mathrm{~km}^{2}$ i.e. it is located between the coordinates $X \mathrm{~min}=$ 7407000 and $X \max =7411000$ and $Y \min =$ 5010500 and $Y \max =5014000$. The overlying layer and bottom layer in the model are defined as average values of elevation 73.5 m.a.s.l. and 58.5 m.a.s.l. and they are constant in the entire area. The initial coefficient of filtration $\mathrm{K}$ was obtained based on the sieve analysis and laboratory measurements. The adopted value of coefficient was $\mathrm{K}=$ $5 \cdot 10^{-4} \mathrm{~m} / \mathrm{s}$. The measurements of groundwater levels in the piezometers used for calibration of the model. The method of analytical elements requires the knowledge of level values in the piezometers at one point - a benchmark set in the piezometer S136 and the value of the measured piezometrical level is 76.74 m.a.s.l. This value is constant throughout the simulation. The Danube River is simulated with linear elements with the level of 75.08 m.a.s.l. on the entire move of the analyzed area.

The four Reny wells RB-5 (30.7 L/s), RB-4 (29.8 L/s), RB-1 (30.7 L/s) i RB-2 (49.6 L/s) were in the work when we making analytical model in the water source Štrand with a total capacity of 140,8 $\mathrm{L} / \mathrm{s}$. The position of the wells is given on Figure 1 .

By varying the value of the regional gradient, the direction of movement of groundwater and the aforementioned parameters were obtained good results with a small deviation of the measured and calculated levels of the groundwater, Table 1. The isolines of the groundwater level in the calibrated model are shown in Figure 3.

After the finished calibration of the analytical model we started the further processing of data based on the numerical model. 
Table 1 - The measured and calculated levels of the groundwater during the calibration model

\begin{tabular}{|c|c|c|c|c|c|c|c|}
\hline Name & Measured value & Calculated value & Diff. & Name & Measured value & Calculated value & Diff. \\
\hline Sh-7 & 72.49 & 71.82 & 0.67 & Sh -15 & 74.05 & 74.04 & 0.01 \\
\hline Sh -8 & 73.04 & 72.54 & 0.50 & Sh -16 & 72.22 & 72.33 & -0.11 \\
\hline Sh -9 & 73.46 & 73.13 & 0.33 & Sh -17 & 73.73 & 73.40 & 0.33 \\
\hline Sh -10 & 74.14 & 74.56 & -0.42 & P-14 & 74.15 & 74.35 & -0.20 \\
\hline Sh -11 & 74.67 & 74.59 & 0.08 & S-26 & 76.08 & 75.94 & 0.14 \\
\hline Sh -12 & 74.66 & 74.47 & 0.19 & S-73 & 75.03 & 75.31 & -0.28 \\
\hline Sh -13 & 74.98 & 74.59 & 0.39 & S-102 & 75.41 & 75.06 & 0.35 \\
\hline Sh -14 & 74.36 & 74.66 & -0.30 & S-112 & 74.15 & 74.45 & -0.30 \\
\hline
\end{tabular}

\subsection{Mathematical modeling by applying the numerical model}

Input data that were used to simulate and display the analytical model are in good agreement with the natural level in the aquifer. Using numerical model of the water source Štrand, which was formed on the basis of the conceptual model, allows us that existing heterogeneity of water source on reliably way analyze and display.

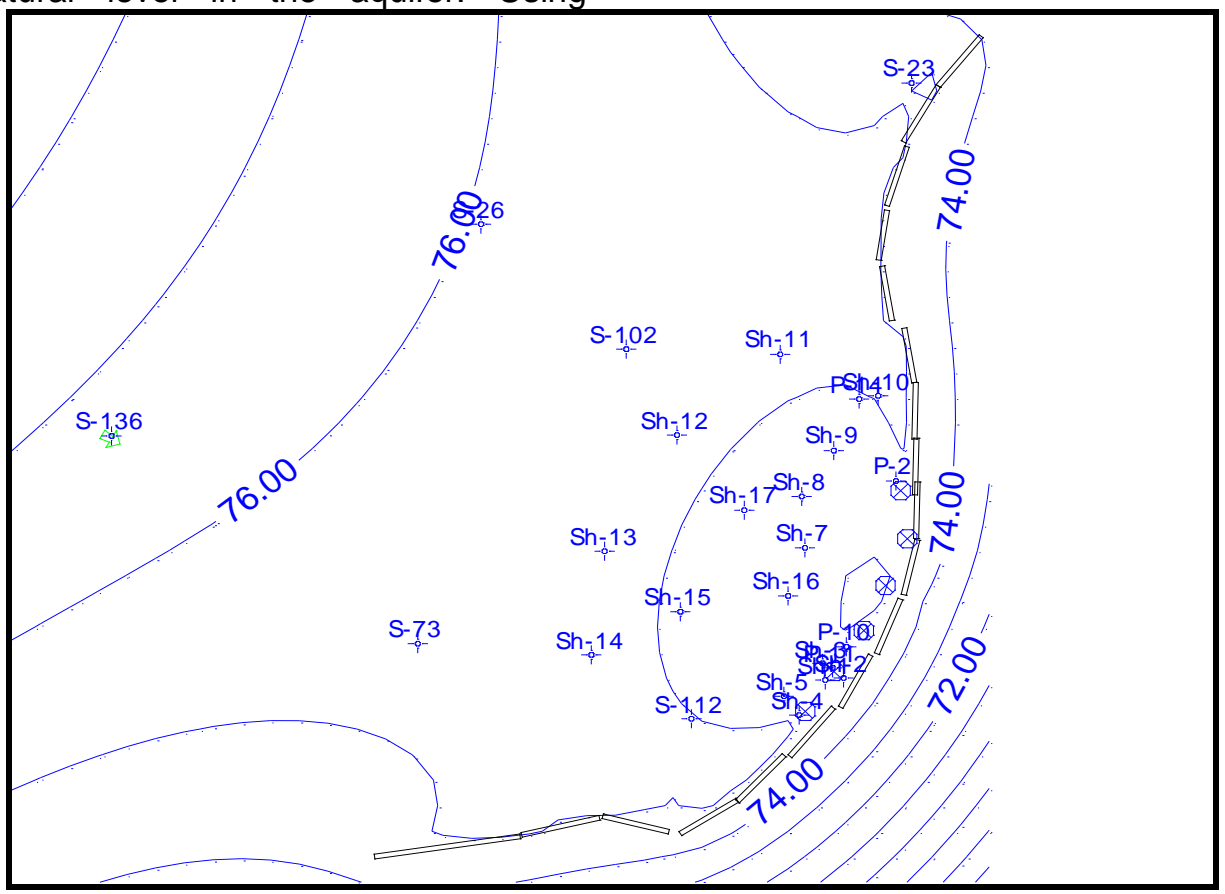

Figure 3 - The isolines of the groundwater level in the water source Štrand, calibrated model

\subsection{Position and surface of model}

Model of Štrand water source includes a part of area of water source where there are flows of groundwater. The area of the space which is covered by numerical model is $3500 \times 3000 \mathrm{~m}$ $\left(10,5 \mathrm{~km}^{2}\right)$ and is placed between field coordinates $\mathrm{Xmin}=7407500$ and $\mathrm{Xmax}=7411000$ and $\mathrm{Ymin}=$ 5010500 and $Y \max =5013500$. This area is part of the water source whose border is the Danube River from east and south. The northern border is represented by coordinate 5013500 and western border of the model is represented by coordinate 7407500. It is the border up to which the influence of pollution from the back part of the water source will be observed. Work conditions of Reny wells remained unchanged when compared to analytical model, i.e. the wells operated in the total capacity of $140.8 \mathrm{~L} / \mathrm{s}$.

\subsection{Discretization of model}

Showing the space i.e. the area occupied by the numerical model was carried out by dividing to cells of the model. The area of the model consist of 120 rows and 141 columns. Each cell has dimensions of $25 \times 25 \mathrm{~m}$. Altitude of the area terrain on the water source Štrand ranges from 80 to 73 m.a.s.l. 
The arrangement of the layers in the model is as follows:

- the first layer of humus, dust and deposit material is located at the height of 78 to 70 m.a.s.l.,

- the second layer of fine-grained sand and sand with clay is located at the height 68 to 56 m.a.s.l. and

- the third layer of water-bearing gravel is located at the height 63 to 51 m.a.s.l.

\subsection{The boundary conditions}

As a basis for determining the boundary conditions of numerical model we used electric picture obtained from preliminary hydrodynamic analysis with the method of analytical elements. The advantages of this approach to defining the boundary conditions of the numerical model, when the borders are hydraulic, i.e. artificial, reflected in their more precise determination from the classic approach that involves interpolation of piezometers

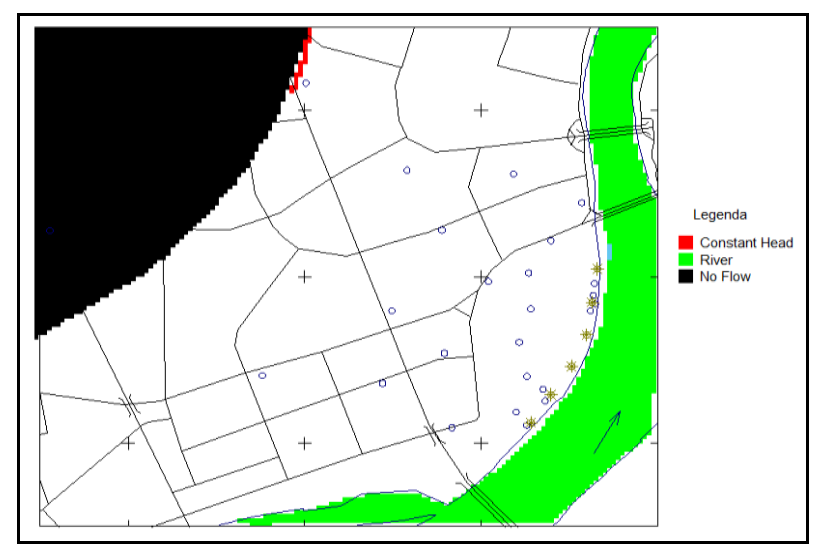

a) levels by computers or manually. Unlike classic methods, which take into account only the point values obtained measurements in the research objects, electric picture obtained with method of analytical elements take into account complete balance.

The boundary conditions of the first, second and third layer of the numerical model are given in Figure 4. Northwest part of the model has cells which we characterized as "No Flow" for all layers. It also defined "Constant Head" boundary conditions on the basis of modeling with mathematical model i.e. defined the cells that have constant level of groundwater for the first and second layer. Eastern and southern border of model is presented with the Danube River. The Danube River is presented as the boundary condition "River" with constant water level of 75.08 m.a.s.l. for the first and second layer. The Danube River is dominant source of recharge of aquifer.

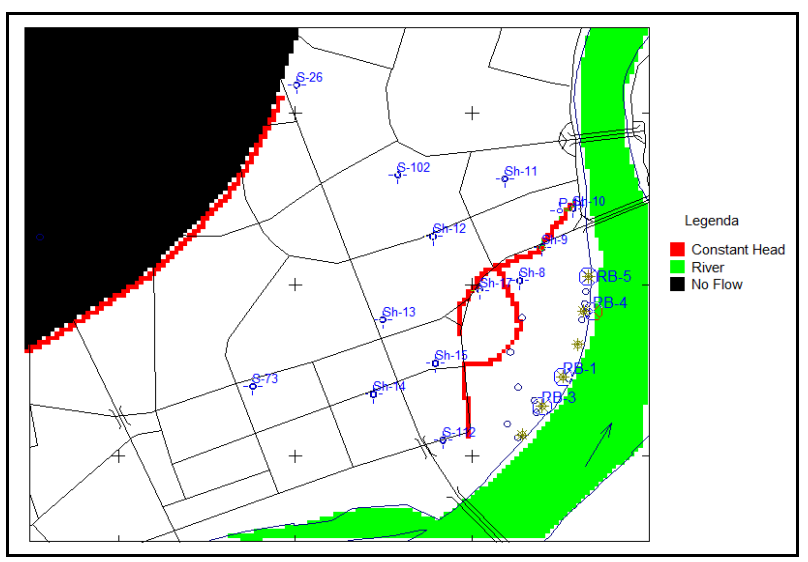

b)

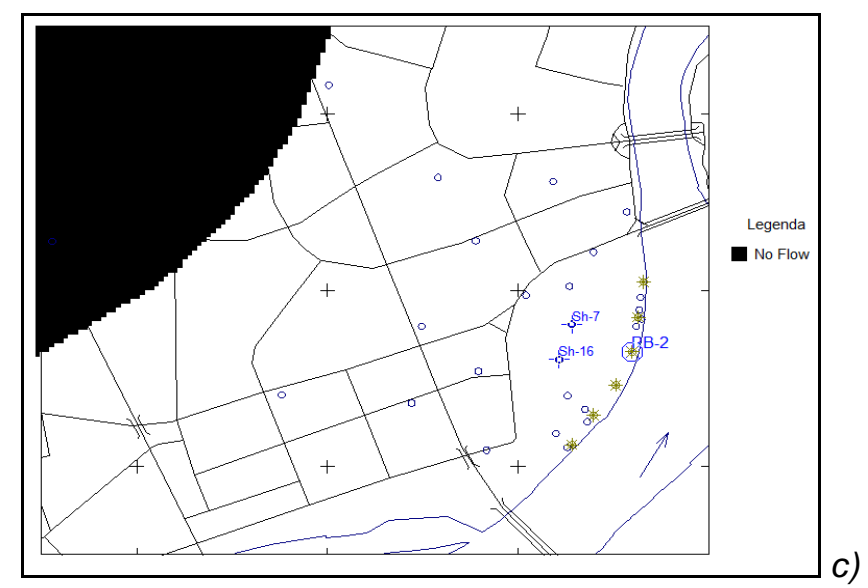

Figure 4 - Discretization and boundary conditions of model:

a) the first layer, b) the second layer, c) the third layer

\subsection{The filtration characteristics}

The spatial position of the observed aquifer is defined on the basis of the results of geological and hydrogeological research in this area. According to the data from the model, the value of the coefficient of filtration for the first, second and third layer are shown in Figure 5. 


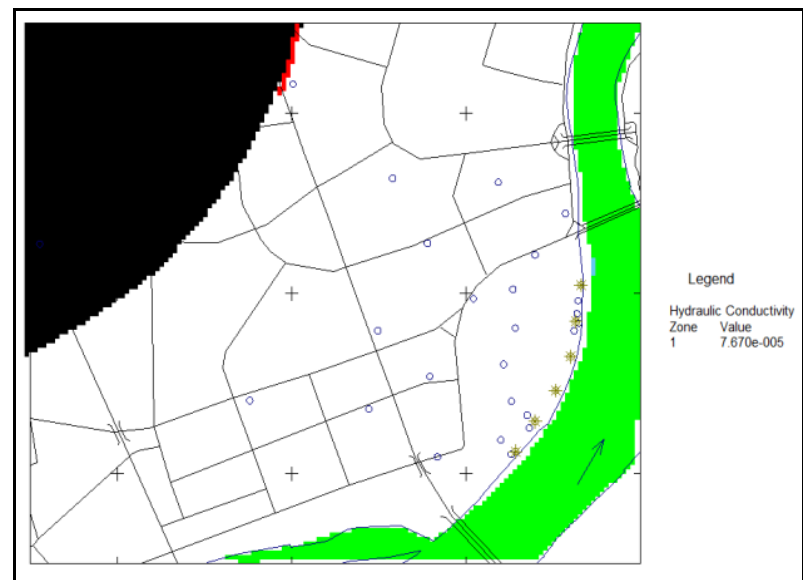

a)

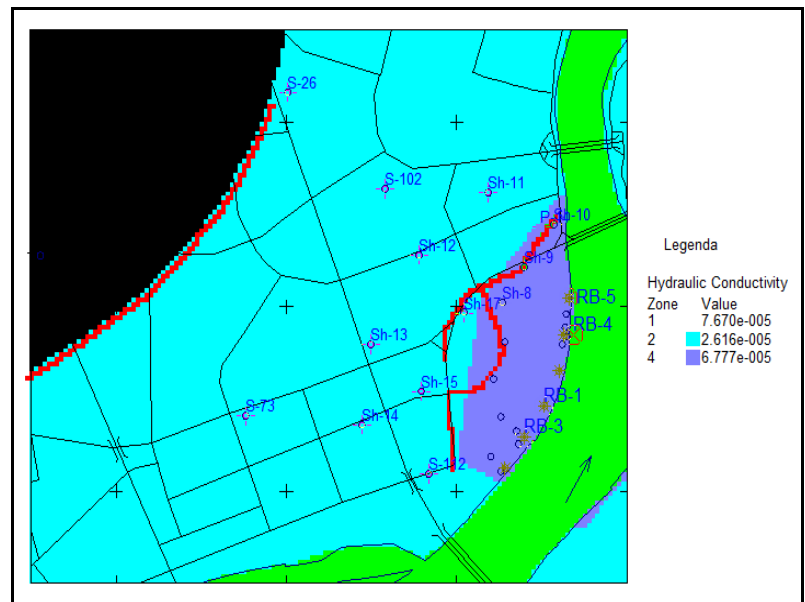

b)

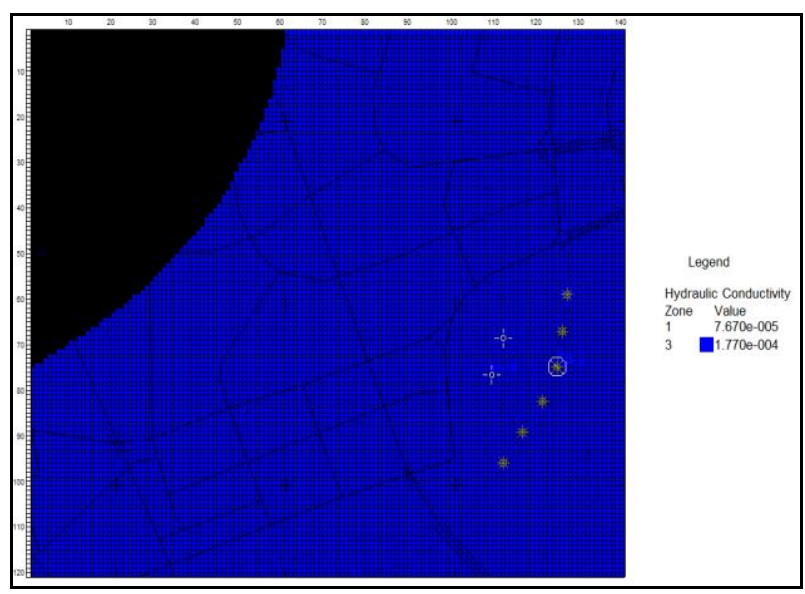

c)

Figure 5 - The coefficients of the filtration of model: a) the first layer, b) the second layer, c) the third layer

The coefficient of the filtration for the first layer is $7.67 \cdot 10^{-5}$ and it is constant throughout the layer (Figure 5 a). The filtration characteristics of the second layer are displayed in two zones that have the value of filtration coefficient of $2.616 \cdot 10^{-5} \mathrm{~m} / \mathrm{s}$ (light blue) and $6.777 \cdot 10^{-5}$ in the zone of the wells at the watersource Štrand (purple). The calibration process of model has its problems, which are reflected in the ambiguity and vagueness of the model [17] (Figure $5 \mathrm{~b}$ ). The filtration characteristics of the third layer at the watersource Štrand, from which the water supply of the city of Novi Sad is performed, have a filtration coefficient of $1.77 \cdot 10$ ${ }^{4} \mathrm{~m} / \mathrm{s}$ (Figure $5 \mathrm{c}$ ).

\section{RESULTS AND DISCUSSION}

\subsection{Model of pollution transport at the water source Štrand}

The reason why the modeling of transport of pollution is done by using vinyl-chloride and sodium is that these pollutants were proven in the aquifer. They are accumulated in the aquifer. The boundary conditions of the model and quantities pumped from aquifer by using wells were remain same as for the numerical model. Pollution transport was shown from the source of pollution that was presented as line pollutant i.e. sevage collector which is located from back part of the water source.

The most unfavorable condition for the infiltration of water from savage collector of $30 \%$ or $0.029 \mathrm{~L} / \mathrm{s}$ per meter of collector is chosen to simulate the pollution transport. Together with the assumed direction of movement of groundwater from south to north, the pollutions are moved. The part of the pollutants are being transported through the layer and the complete amount of pollution doed not go to zone of Reny wells.

The input concentration for the modeling of pollution transport with vinyl-chloride was determined by analyzing the water quality in savage collector GC-1. Based on the analysis, it concentration of vinyl-chloride was determined from 4.2 $\mu \mathrm{g} / \mathrm{l}$ and trichlorethylene $113 \mu \mathrm{g} / \mathrm{l}$. The sum of $117.2 \mu \mathrm{g} / \mathrm{l}$ represents the input concentration of the vinyl-chloride for the modeling, because vinyl-chloride is obtained with decomposition of trichlorethylene in the groundwater. The input concentration for the modeling of pollution transport with sodium is $1200 \mathrm{mg} / \mathrm{l}$. The simulation of pollution transport using vinyl-chloride include all physical-chemical reactions in the layer and bioremediation. The simulation of sodium transport is seen as transport of ideal tracer.

Pollution transport of vinyl-chloride (Figure 6 and 7) and sodium (Figure 8 and 9) are presented separately for the second and third water intake layer and set aside for the period of 3 mounts, detection of pollution in the water intakes objects and for the period of 60 mounts. 
3.2. Transport of vinyl-chloride in the second layer
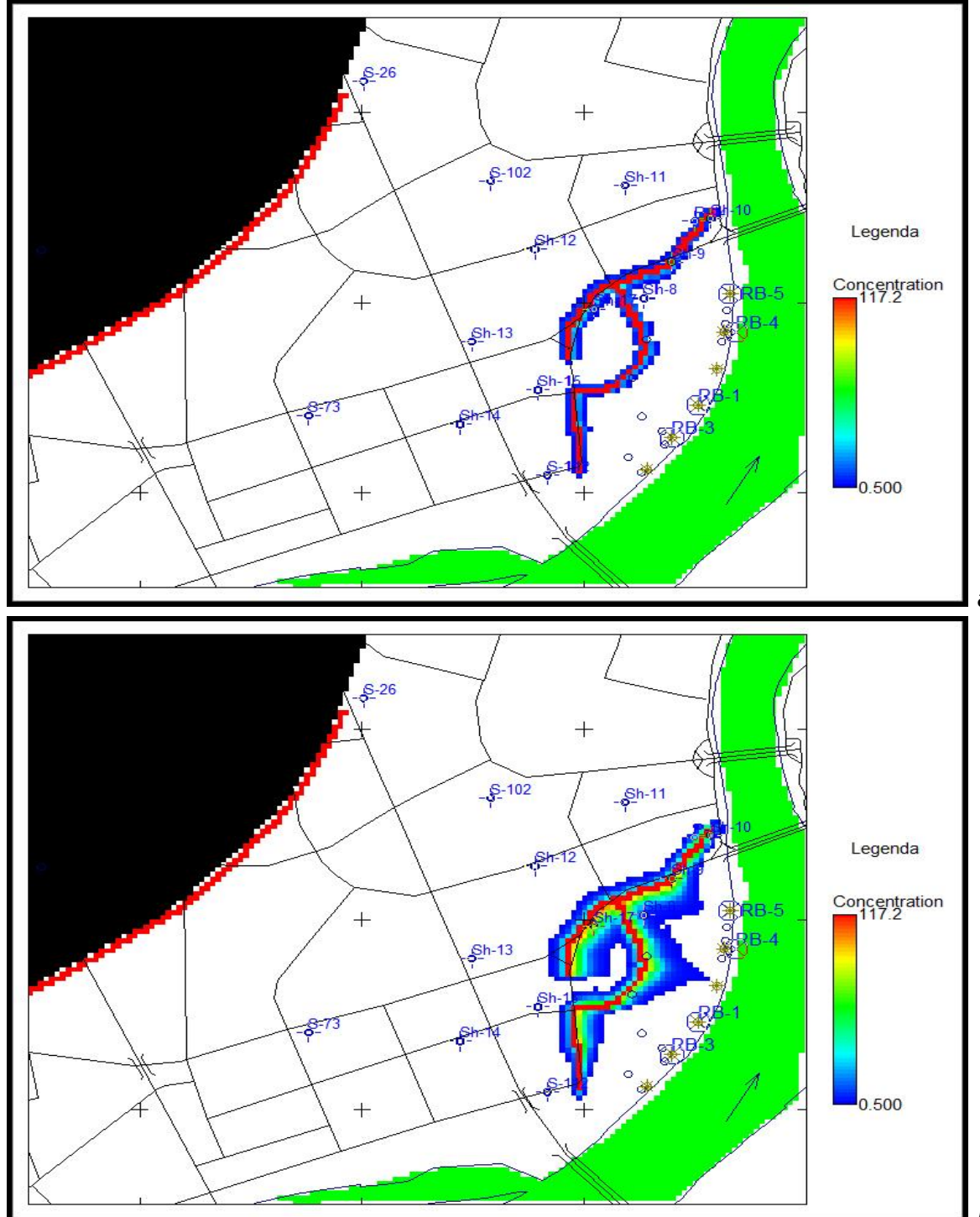

a)

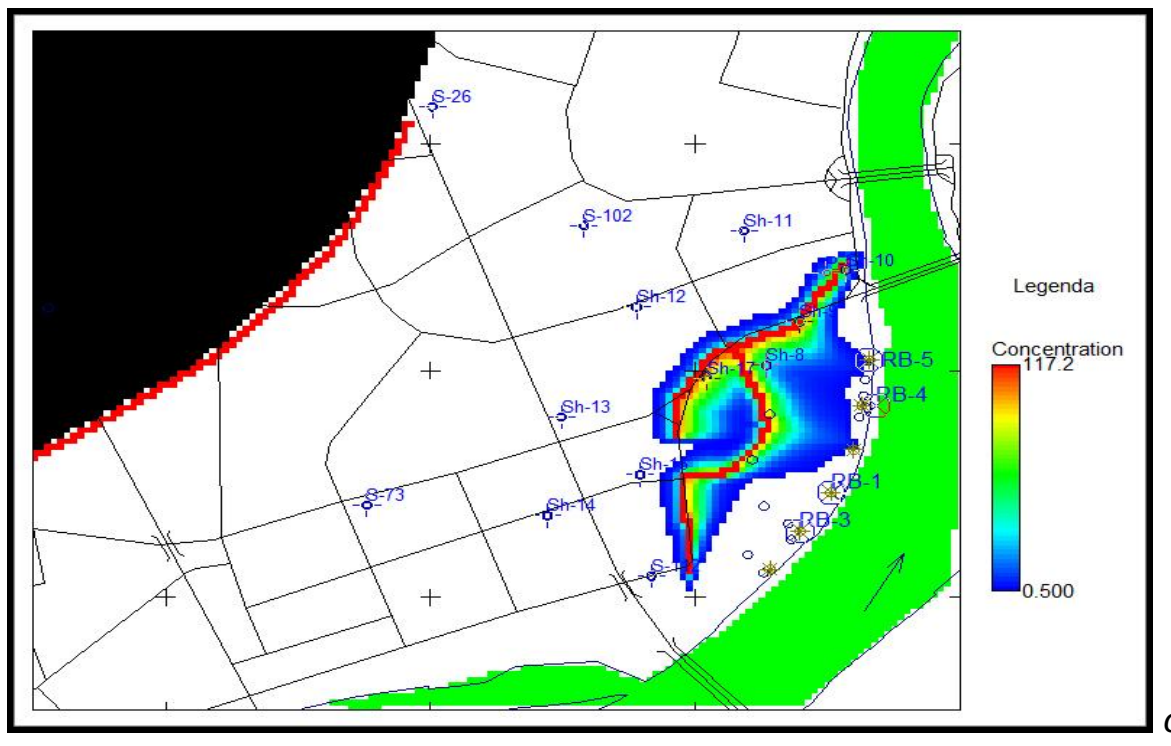

b)

Figure 6 - Pollution transport of vinyl-chloride in the second layer:

a) 3 months, b) detection of pollution in the water intakes objects, c) 60 months 
3.3. Transport of vinyl-chloride in the third layer
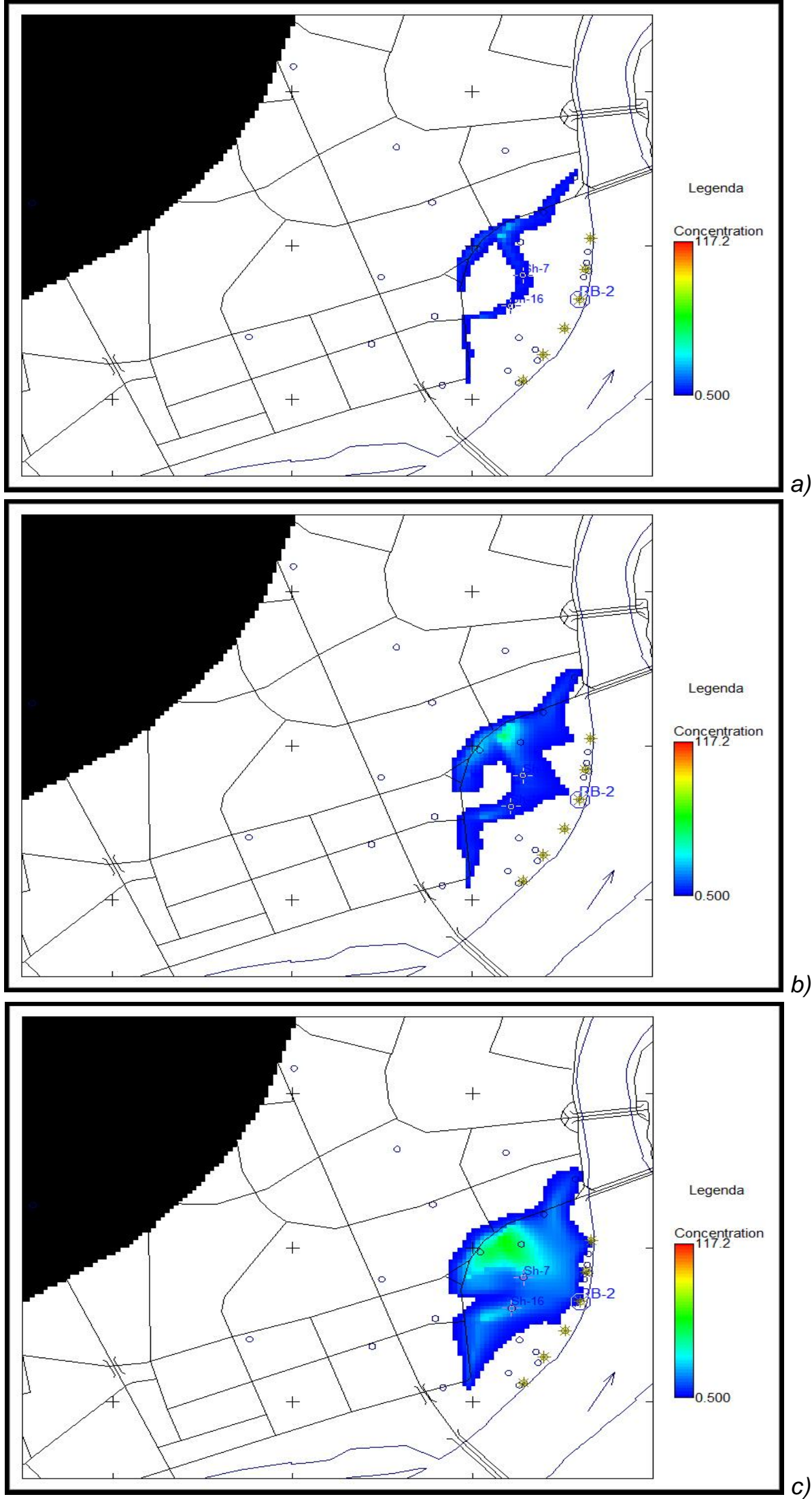

b)

Figure 7 - Pollution transport of vinyl-chloride in the second layer:

a) 3 months, b) detection of pollution in the water intakes objects, c) 60 months 


\subsection{Transport of sodium in the second layer}
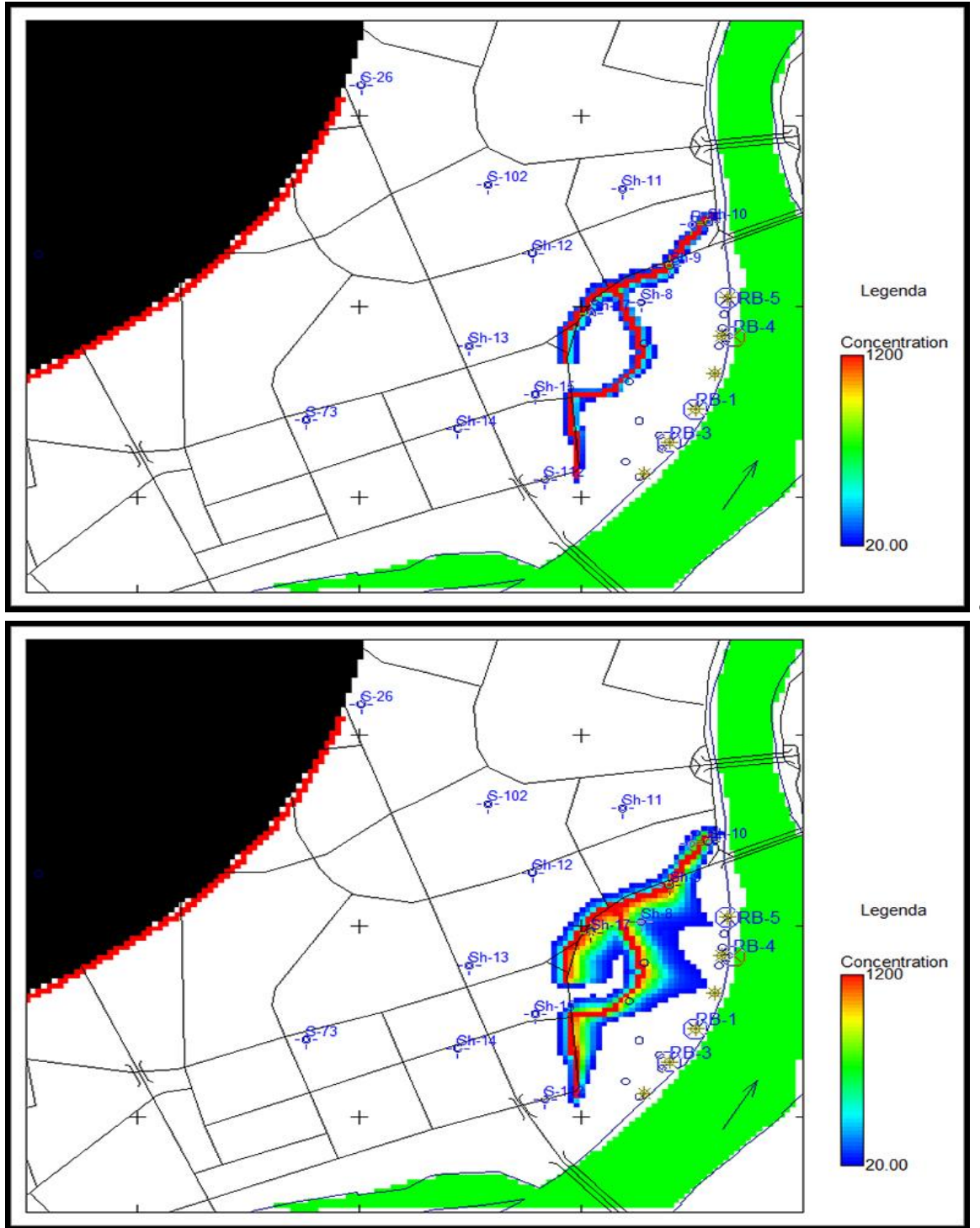

a)

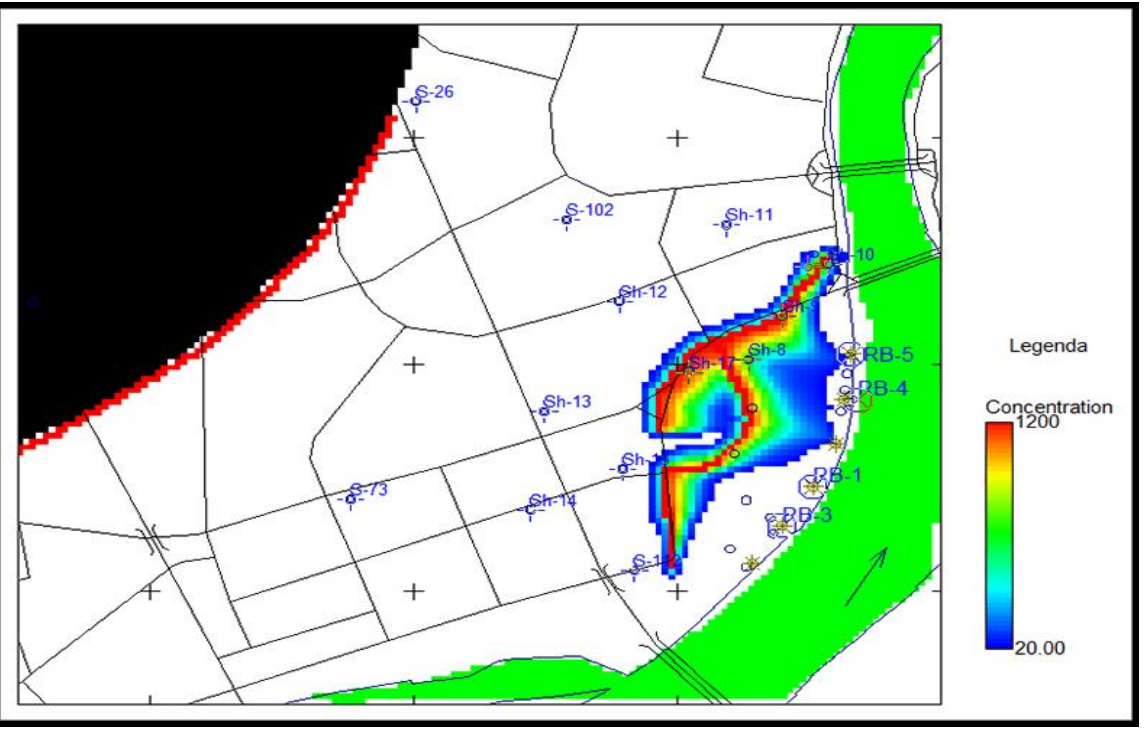

b)

Figure 8. Pollution transport of sodium in the second layer:

a) 3 months, b) detection of pollution in the water intakes objects, c) 60 months 


\subsection{Transport of sodium in the third layer}
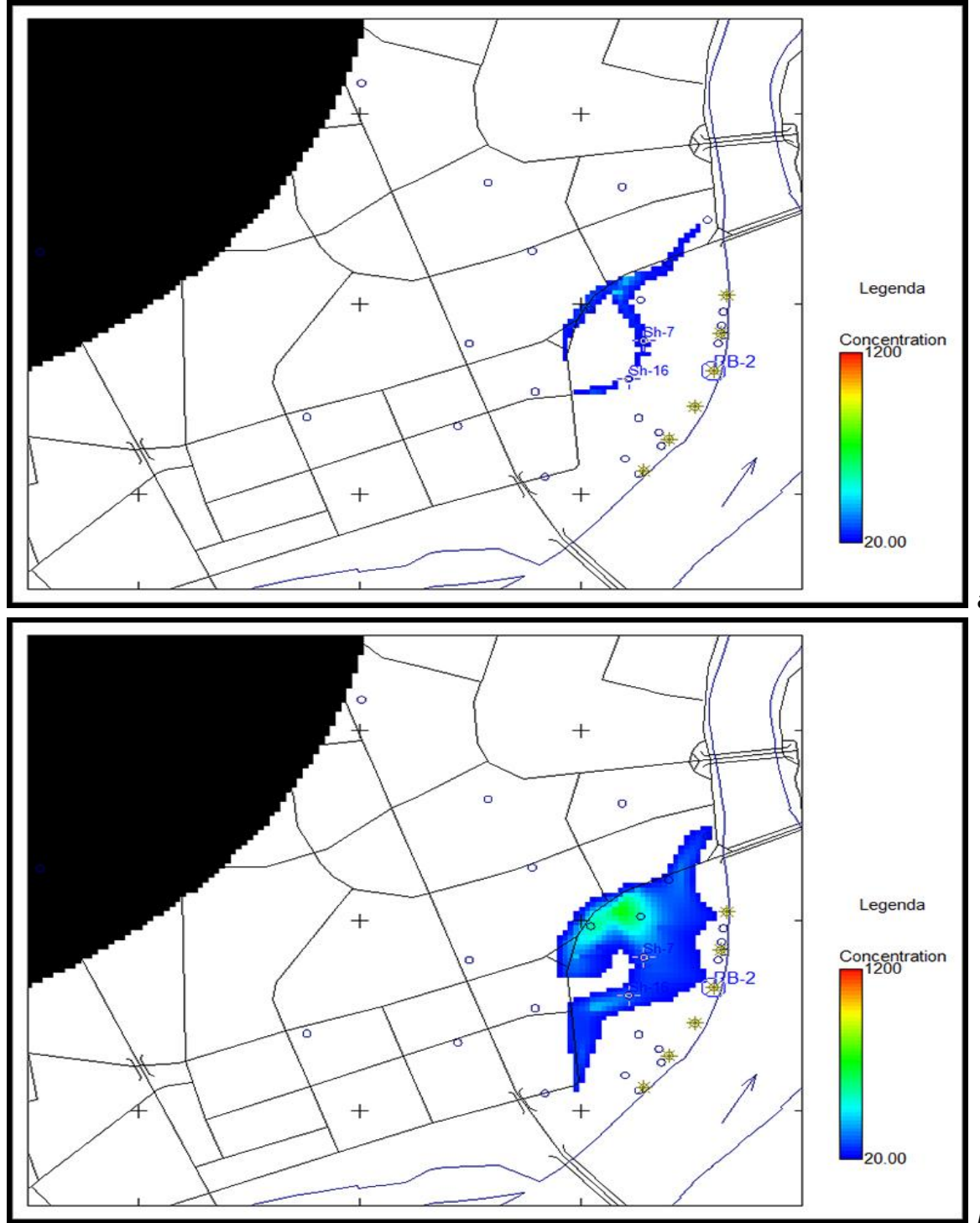

a)

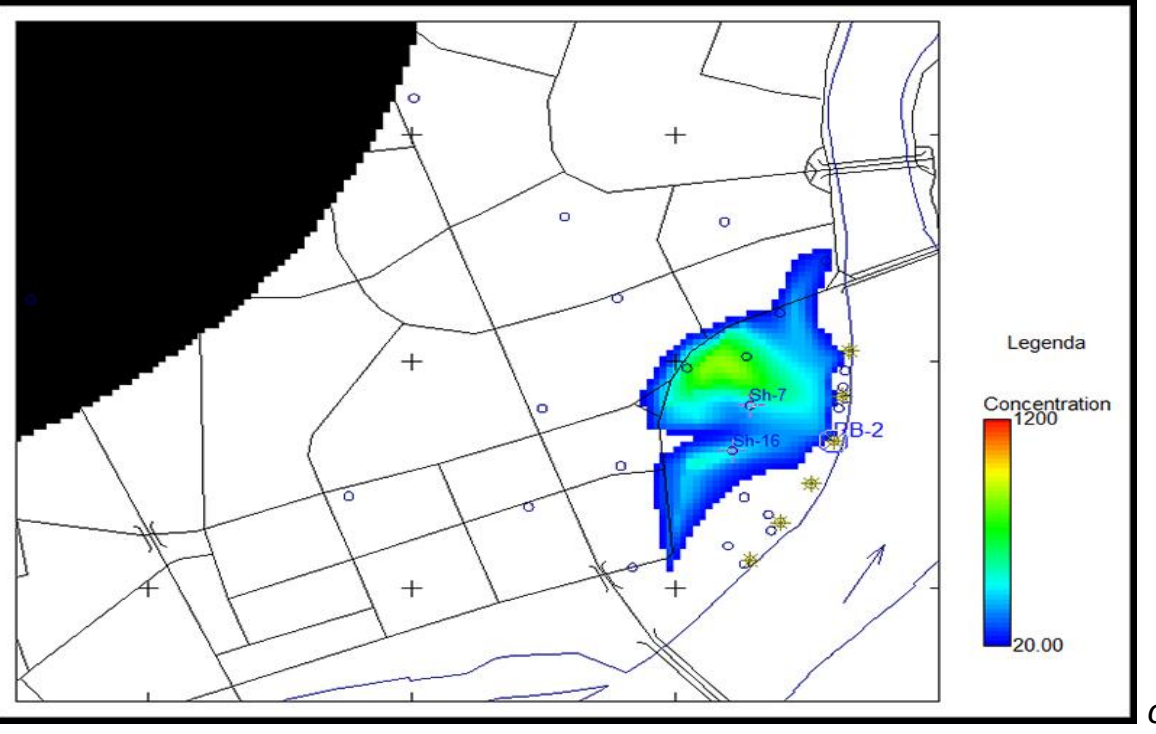

b)

Figure 9 - Pollution transport of sodium in the third layer:

a) 3 months, b) detection of pollution in the water intakes objects, c) 60 months 


\section{CONCLUSION}

1. The time and degree of pollution that can be expected in specific circumstances in the water source in the city of Novi Sad can be predicted by analysis of the pollution transport in the groundwaters through hydraulic conditions prevailing in aquifer intergranular porosity. This analysis can be applied to other environments such as Semberija, Posavina, Lijevče polje etc.

2. The connection between pollution source (savage collector located behind water source) with the present pollution in the piezometers and wells was proved by mathematical model of pollution transport for the water source Štrand. This model can determine the direction, speed and time of pollution transport from the source of pollution to the water intake objects. In this paper the following methods of mathematical modeling were used: mathematical modeling with the method of analytical elements using the program Aquifer Win 32 and mathematical modeling using the 3D mathematical models using the program Groundwater Vistas version 6. Transport of pollutions was monitored with vinyl-chloride which is a typical representative of the pollution from industry and thorugh sodium which is representative of anthropogenic pollution.

3. Using mathematical models of pollution transport for the water source Strand the following has been shown: for the period of 12 mounts vinylchloride will come to the wells in the water source zone in the third water intake layer. In the second layer, the migration of pollution to the wells will be realized for a period of 36 months. Differences in the rate of pollution transport are the result of unequal coefficients of filtration of layers.

4. The pollution with sodium will reach the wells in the water source zone for only $\mathbf{2 4}$ months in the third layer, and for 36 months in the second layer. Differences in the rate of pollution transport are the result of unequal coefficients of filtration of layers and dilution what happened in the water layers.

5. The results of the mathematical model of pollution transport for the water source Štrand require to carry out the repair or relocation of pollution source behind of the water source. If this is not possible, it is necessary to build a hydraulic barrier that will not allow the passage of pollutants to the wells.

\section{REFERENCES}

[1] Elaborat o prikupljanu i reinterpretaciji geoloških i hidrogeoloških podataka na širem području Novog Sada (1978) Građevinski fakultet, Subotica.
[2] Tehnički izvještaj o izvršenim radovima na ispitivanju Reny bunara RB-3 na izvorištu Štrand (1995) Aquatic, Novi Sad.

[3] Rezultati namjenskih istraživanja u cilju utvrđivanja procesa starenja i opravdanosti utiskivanja drenova u bunaru RB-III na izvorištu Štrand u Novom Sadu (2004) Institut za vodoprivredu "Jaroslav Černi" Beograd

[4] Elaborat o rezervama podzemnih voda izvorišta novosadskog vodovoda (2009) Hidrozavod DTD, Novi Sad.

[5] B.Dalmacija, S.Kolaković, M.Klašnja, I.IvančevTumbas, J.Benek, M. Vasiljević, S. Kulačin, R. Cinkler, S.Milosavljević, S.Repac (2009) Strategija vodosnabdevanja i zaštite voda u AP Bojvodini, Prirodno-matematički fakultet, Departman za hemiju, Novi Sad

[6] M.Dimkić, H.J.Brauch, M. Kavanaugh (2008) Groundwater management in large river basins. IWA publishing, London.

[7] M.Dimkić, M.Pušić, D.Vidović, D.Đurić, D. BoreliZdravković (2013) Analiza transporta zagađenja kod određivanja zona sanitarne zastite izvorista podzemnih voda. Vodoprivreda, 45(4-6), 203-218

[8] D. Kaluđerović (2009) 3D matematički modeli kretanja podzemnih voda i transporta zagađenja u hidrogeologiji, AMG Knjiga, Beograd.

[9] J.Bear, A. H.D.Cheng (2010) Modeling groundwater flow and contaminant transport. Springer Dordrecht, Heidelberg, London, New York.

[10] B.S.Jovanović (1989) Numericke metode rešavanja parcijalnih diferencijalnih jednačina, Savremena računska tehnika i njena primena, vol.8, Mat.Institut, Beograd.

[11] M.Thangarajan (1999) Quantification of pollutant migration in the groundwater regime through mathematical modelling, Current Science, 76(1), 7381.

[12] M.P.Anderson, J.A.Cherry, (1997) Using Models to Simulate the Movement of Contaminants through Ground Water Flow System, C R C Critical Reviews in Environmental Control, 9 (2), 97-156.

[13] M. P.Anderson (1984) Movement of Contaminants in Groundwater: Groundwater Transport - Advection and Dispersion, from Groundwater Contamination, 37-45 p., National Academy Press.

[14] C.Zheng, G.Bennett (2002) Applied contaminant transport modelling. Second Edition. New York, USA. John Wiley and Sons, Inc.

[15] V.Batu (2006) Applied Flow and Solute Transport Modeling in Aquifers: Fundamental Principles and Analytical and Numerical Methods, p.667, CRC Press.

[16] http://www.eosremediation.com/portfolio-items/fateof-vinyl-chloride-in-aquifers/

[17] D.Kaluđerović (2014) Analiza neodređenosti rezultata kalibracije matematičkog modela izvorišta u Trnovču metodom Null space Monte Carlo, Voda i sanitarna tehnika, 2, 34-42. 


\section{IZVOD}

\section{MODELOVANJE TRANSPORTA ZAGAĐUJUĆIH MATERIJA U ALUVIJALNIM SEDIMENTIMA RIJEKE DUNAV KOD NOVOG SADA}

Fizičko-hemijske i mikrbiološke analaze vode iz aluvijalnih sedimenata rijeke Dunav i sedimenta riječnog korita pokazuju prisutno zagađenja organskog i neorganskog porijekla. Uzorci su analizirani prema propisanim standardnim metodama za određivanje higijenske ispravnosti vode za piće. Analizirano je i prisustvo teških metala, specifičnih organskih materija, ukupnih ugljovodonika, mineralnih ulja, pesticida i organskih profila vode GC/MS analizom. Za hemijsku analizu komponenata prisutnih $u$ vodi korišteni su IR spektrofotometar, gasni hromatograf sa masenim detektorom - koji ima mogućnost kvalitativne analize jedinjenja u količini iznad 1 ppm $i$ kvantitativne analize pojedinih određivanih toksičnih jedinjenja u količini iznad 1 ppb. Određivanje koliformnih bakterija vršeno je membran filter metodom. Prisustvo zagađujućih materija je otkriveno u skoro svim pijezometrima i bunarima tokom monitoringa podzemne vode. Zbog prisutnog zagađenja urađen je matematički model transporta zagađenja na izvorištu Štrand. Transport zagađenja je modelovan za dva parametra: vinil-hlorid kao karakteristični predstavnik zagađenja iz industrije i natrijum koji predstavlja reprezentativni vid antropogenog zagađenja nastalog u domaćinstvima.

Ključne riječi: analiza, aluvijon, sediment, transport, zagađenje, matematički model.

Naučni rad

Rad primljen: 20. 04. 2016.

Rad prihvaćen: 22. 05. 2016.

Rad je dostupan na sajtu: www.idk.org.rs/casopis 